\title{
Do The Federal Deficits Matter?
}

Sayeed Payesteh, (Email: sayeed.payesteh@uwc.edu), University of Wisconsin-Fond du Lac

\begin{abstract}
The sharp and sustained increases in the budget and current-account deficits have once again raised a great deal of concern among many economists on the reemergence of the twin deficits of the1980s and their impacts upon macroeconomic variables. In view of majority of economists, these developments will be creating economic problems such as high real rates of interest, low savings, stagnant economic growth, large and persistent current account deficits, and probably a higher inflation. All economists, however, do not share this view. Those associated with the writings of Robert Barro, argue the Ricardian Equivalence Theorem that budget deficits do not matter and they have no real effects on the economy. The empirical evidence on this issue has been rather inconclusive. In contrast to the previous studies that have used single equation, I use a balance of payment model to investigate simultaneously the impacts of budget deficits on a number of macroeconomic variables using a system of simultaneous equations.
\end{abstract}

\section{INTRODUCTION}

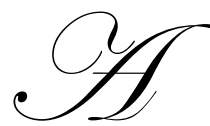

$t$ the beginning of 1980, the size of the Federal government outstanding gross debt amounted to $\$ 700$ billion and the federal deficits were only $\$ 16.1$ billion. When President Reagan came to office at the beginning of 1981, national debt was $\$ 909$ billion which was 33 percent of gross domestic product (GDP) and the federal government budget deficits were $\$ 61.3$ billion. At the end of 1995 fiscal year, national debt was over $\$ 5$ trillion and the federal deficits were $\$ 185$ billion. At around the end of the fiscal year 2005 , the budget deficits exceeds $\$ 400$ billion and national debt is over $\$ 7.9$ trillion. In addition to substantial increase in the national debt, the net international investment position of the United State has deteriorated as well. In 1981 the U.S. was a net international lender. However, as a result of persistent large trade deficits U.S. became a net debtor in recent years.

In view of majority of economists, these developments will be creating economic problems such as high real rates of interest, low savings, stagnant economic growth, large and persistent current account deficits, and probably a higher inflation. All economists, however, do not share this view. Those associated with the writings of Robert Barro, argue that budget deficits do not matter and they have no real effects on the economy. Robert Barro (1987 \& 1989), argues the Ricardian equivalence proposition that if government finances its expenditure by borrowing, the public will realize that it will only have to pay higher taxes in the future to service the government debt. Thus, deficit merely postpones taxes and private sector will have to save more to face higher tax in the future. Therefore, decrease in government saving, i.e., a current budget deficit, leads to an offsetting increase in desired private saving, and hence there is no change in desired national saving. Since national saving does not change, the real interest rate does not have to rise in a closed economy to maintain balance between desired national saving and investment demand. Also in an open economy, there would be no effect on current account balance because the increase in desired private saving prevents borrowing from abroad. So budget deficits do not lead to current account deficits. This is a conclusion, which contradicts the conventional view of budget deficit. According to the conventional view, the substitution of budget deficit for current taxation will result in an increase in the current disposable income and hence in an increase in aggregate consumption. Private saving will also rise but by less than the tax cut, so that desired national saving will decrease. For a closed economy, real interest rates must rise to insure the equality of saving and investment. Thus budget deficit should place upward pressure on interest rate. In an open economy however, decrease in national saving will be offset by increase in borrowing from abroad rather than increase in interest rate. That is, budget deficit will contribute to capital inflows and hence to trade deficits. 
The primary purpose of this study is to assess the impacts of U.S. federal budget deficits on trade balance, Capital inflows, exchange rates, and interest rates using a system of simultaneous equations within a balance of payment model. Section II contains a review of the literature as it relates to these areas. The theoretical model and the methodology are presented in section III. Section IV reports the empirical results. Section V concludes.

\section{THE METHODOLOGY}

In contrast to the previous studies that have used a single equation, I use a balance of payment model to investigate simultaneously the impacts of budget deficits on as many macroeconomic variables as possible. Moreover, most of these studies have estimated their regression equations in the presence of high degree of multicollinearity that exists among the explanatory variables in their model. Hence, the precision of their results are questionable. Variance inflation factor, (a measure of multicollinearity that has been in the literature for a long time, but has not been used in applied econometrics) is used to assess the degree of collinearity that exists among the explanatory variables.

\section{Theoretical Specification Of The Model}

A similar balance-of-payments model used by Haas and Alexander, has been employed to investigate the effects budget deficits on trade deficit, capital flows, exchange rate, and interest rate.

$\mathrm{TB}=\mathrm{f}\left(\mathrm{E}, \mathrm{BD}, \mathrm{Y}, \mathrm{Y}^{*}, \mathrm{M}, \mathrm{M}^{*}, \mathrm{TOT}\right)$

$\mathrm{CF}=\mathrm{g}\left(\mathrm{E}, \mathrm{BD}, \mathrm{R}, \mathrm{R}^{*}, \mathrm{Y}, \mathrm{Y}^{*}\right)$

$\mathrm{E}=\mathrm{h}\left(\mathrm{CF}, \mathrm{BD}, \mathrm{R}, \mathrm{R}^{*}, \mathrm{Y}, \mathrm{Y}^{*}\right)$

$\mathrm{R}=\mathrm{R}(\mathrm{E}, \mathrm{BD}, \mathrm{Y}, \mathrm{M}, \mathrm{CF})$

$\mathrm{TB}+\mathrm{CF}-\mathrm{OP}=0$

Where,

$\mathrm{TB}=$ trade balance (defined as imports minus exports)

$\mathrm{CF}=$ net capital flow

$\mathrm{E}=$ effective spot exchange rate (defined as number of foreign currency per unit of domestic currency)

$\mathrm{R}=$ domestic interest rate

$\mathrm{BD}=$ budget surplus (deficit) if positive (negative)

$\mathrm{Y}=$ measure of domestic income

$\mathrm{Y}^{*}=$ world income

$\mathrm{M}=$ domestic money supply

$\mathrm{M}^{*}=$ world money supply

$\mathrm{R}^{*}=$ rest of the world interest rate

$\mathrm{PX}=$ index of export price

$\mathrm{PM}=$ index of import price

$\mathrm{TOT}=$ terms of trade, defined as PX/PM

$\mathrm{OP}=$ official purchases of foreign exchange, a policy determined variable.

The model is a five-equation system in twelve variables (TB, CF, E, R, BD, Y, $\mathrm{Y}^{*}, \mathrm{M}, \mathrm{M}^{*}, \mathrm{R}^{*}$, TOT, OP). TB, $\mathrm{CF}, \mathrm{E}$, and $\mathrm{R}$ are endogenous variables. The remaining variables are exogenous. The values of exogenous variables are completely determined out side of the system. One may argue that the federal budget variable should rather be endogenous. For example, Eisner (1987) argues that in order to study the impact of budget deficit on the economy one must first recognize that the deficit is in large part endogenous in the economic system, that is, the economy affects deficit too. During recessionary periods national income falls and so do the tax receipts, and at the same time payouts of unemployment benefits rise. Hence, recessions bring on or increase deficits. On the other hand prosperity and booms will correspondingly reduce or eliminate deficits. I use cyclically adjusted federal budget, also adjusted for seasonal 
variation. I used this definition of budget rather than actual budget, because this definition is not sensitive to changes in economic conditions. Thus, any change in government budget position reflects the stance of fiscal.

Since there are endogenous variables among the explanatory variables in the simultaneous equations, ordinary least squares estimators of the structural coefficients are not consistent (Johnston, 1984 p. 440). Thus, the estimates of the structural parameters can be obtained by estimating these equations simultaneously. The estimation technique being used for this model is the two stage least squares.

\section{EMPIRICAL RESULTS}

\section{Trade Balance Equation}

The linearized equation for the U.S. trade balance could be written as

$\mathrm{TB}=\mathrm{a}_{10}+\mathrm{a}_{11} \mathrm{E}+\mathrm{a}_{12} \mathrm{BD}+\mathrm{a}_{13} \mathrm{Y}+{ }_{14} \mathrm{Y}^{*}+\mathrm{a}_{15} \mathrm{M}+\mathrm{a}_{16} \mathrm{M}^{*}+\mathrm{a}_{17} \mathrm{TOT}+\mathrm{u}_{1}$

The expected theoretical sign of the coefficients are as follows:

$\begin{array}{llllllll}\text { Variable: } & \mathrm{E} & \mathrm{BD} & \mathrm{Y} & \mathrm{Y}^{*} & \mathrm{M} & \mathrm{M}^{*} & \text { TOT } \\ \text { Sign: } & - & - & + & - & + & - & +\end{array}$

Table 1: Coefficient Estimates of Trade Balance Equation

\begin{tabular}{|c|c|c|c|c|c|}
\hline Predictor & Coef & SDV & t-ratio & $\mathbf{p}^{*}$ & VIF \\
\hline Constant & -154.85 & 30.94 & -5.01 & 0.000 & \\
\hline $\mathrm{BD}$ & -0.01398 & 0.04052 & -0.34 & 0.731 & 38.0 \\
\hline TOT & 4.353 & 9.082 & 0.48 & 0.634 & 3.1 \\
\hline $\mathrm{Y}^{*}$ & 1.0267 & 0.1953 & 5.26 & 0.000 & 30.4 \\
\hline $\mathrm{Y}$ & -0.019459 & 0.007418 & -2.62 & 0.011 & 389.3 \\
\hline$E^{*}$ & 0.3265 & 0.1248 & 2.62 & 0.011 & 15.7 \\
\hline $\mathrm{M}^{*}$ & -0.10801 & 0.04165 & -2.59 & 0.012 & 54.2 \\
\hline M & 0.17256 & 0.04943 & 3.49 & 0.001 & 384.4 \\
\hline
\end{tabular}

Table 2: Trade Balance Equation Excluding Y

\begin{tabular}{llllll}
\hline Predictor & Coef & SDV & t-ratio & p & VIF \\
\hline Constant & -93.13 & 21.10 & -4.41 & 0.000 & 21.0 \\
BD & -0.08510 & 0.03162 & -2.69 & 0.009 & 2.2 \\
TOT & 17.102 & 8.058 & 2.12 & 0.038 & 10.2 \\
Y* & 0.6088 & 0.1187 & 5.13 & 0.000 & 3.3 \\
E* & 0.03595 & 0.06032 & 0.60 & 0.554 & 54.0 \\
M* & -0.11431 & 0.04367 & -2.62 & 0.011 & 86.1 \\
M & 0.05835 & 0.02457 & 2.37 & 0.021 & \\
\hline
\end{tabular}


Table 3: Trade Balance Equation Excluding $M$ and $Y$

\begin{tabular}{llllll}
\hline Predictor & Coef & SDV & t-ratio & p & VIF \\
\hline Constant & -84.75 & 21.61 & -3.92 & 0.000 & \\
BD & -0.12795 & 0.02698 & -4.74 & 0.000 & 14.1 \\
TOT & 12.089 & 8.082 & 1.50 & 0.140 & 2.1 \\
Y* $^{*}$ & 0.6516 & 0.1219 & 5.35 & 0.000 & 9.9 \\
I $^{*}$ & 0.02196 & 0.06238 & 0.35 & 0.726 & 3.3 \\
\hline $\mathrm{R}^{2}=93.5 \%,(\mathrm{adj}) \mathrm{R}^{2}=93.0 \%$ & -0.0240 & 0.02229 & -1.08 & 0.286 & 13.0 \\
\hline
\end{tabular}

Table 4: Trade Balance Equation Excluding M, M*, Y, \& YW

\begin{tabular}{llllll}
\hline Predictor & Coef & SDV & t-ratio & p & VIF \\
\hline Constant & 31.500 & 8.111 & 3.88 & 0.000 & \\
BD & -0.21883 & 0.01086 & -20.14 & 0.000 & 1.5 \\
TOT & -19.132 & 6.914 & -2.77 & 0.008 & 1.0 \\
E* & -0.16025 & 0.05196 & -3.08 & 0.003 & 1.5 \\
\hline
\end{tabular}

R-sq $=89.9 \% \quad$ R-sq(adj) $=89.4 \%$

\section{Capital Flow Equation}

It is assumed that $\mathrm{CF}$ depends in an approximately linear fashion to spot rate $\mathrm{E}$, budget deficit BD, domestic and foreign interest rates $\mathrm{R}$ and $\mathrm{R}^{*}$, domestic and foreign real income $\mathrm{Y}$ and $\mathrm{Y}^{*}$. Thus, the capital flow equation becomes

$C F=a_{20}+a_{21} E+a_{22} B D+a_{23} R^{*}+a_{24} R+a_{25} Y+a_{26} Y^{*}+u_{2}$

Table 5: Coefficient Estimates of Capital Flow Equation

\begin{tabular}{llllll}
\hline Predictor & Coef & SDV & t-ratio & p & VIF \\
\hline Constant & -538.343 & 5.080 & -105.98 & 0.000 & \\
BD & 1.3322 & 0.01383 & 96.32 & 0.000 & 98.3 \\
$\mathrm{R}^{*}$ & -0.2066 & 0.04239 & -4.87 & 0.000 & 2.40 \\
$\mathrm{E}^{*}$ & 2.6118 & 0.02336 & 111.80 & 0.000 & 12.3 \\
$\mathrm{Y}^{*}$ & 3.4928 & 0.03811 & 91.66 & 0.000 & 25.7 \\
$\mathrm{Y}$ & 0.0311 & 0.00049 & 62.83 & 0.000 & 38.6 \\
$\mathrm{R}^{\prime}$ & -17.3273 & 0.1674 & -103.53 & 0.000 & 16.0 \\
$\mathrm{R}^{2}=99.8 \%$ & (adj)R ${ }^{2}=99.8 \%$ & & & &
\end{tabular}

Table 6: Capital Flow Equation Excluding BD

\begin{tabular}{llllll}
\hline Predictor & Coef & SDV & t-ratio & p & VIF \\
\hline Constant & -160.38 & 40.93 & -3.92 & 0.000 & \\
$\mathrm{R}^{*}$ & 0.1255 & 0.5360 & 0.23 & 0.816 & 2.4 \\
$\mathrm{E}^{*}$ & 0.5376 & 0.1149 & 4.68 & 0.000 & 1.8 \\
$\mathrm{Y}^{*}$ & 1.1544 & 0.3727 & 3.10 & 0.003 & 15.3 \\
$\mathrm{Y}$ & -0.004540 & 0.00417 & -1.09 & 0.281 & 17.0 \\
$\mathrm{R}^{\prime}$ & -2.4949 & 0.8317 & -3.00 & 0.004 & 2.4 \\
\hline $\mathrm{R}^{2}=67.4 \%$ & $(\mathrm{adj}) \mathrm{R}^{2}=64.6 \%$ & & & &
\end{tabular}


Table 7: Capital Flow Equation Excluding $Y$ and $Y^{*}$

\begin{tabular}{llllll}
\hline Predictor & Coef & SDV & t-ratio & p & VIF \\
\hline Constant & -23.71 & 12.52 & -1.89 & 0.063 & \\
BD & -0.15231 & 0.02720 & -5.60 & 0.000 & 1.8 \\
R* & 0.1849 & 0.6177 & 0.30 & 0.766 & 2.4 \\
E* & 0.1688 & 0.1228 & 1.37 & 0.175 & 1.6 \\
R $^{*}$ & -0.4036 & 0.9680 & -0.42 & 0.678 & 2.5 \\
\hline
\end{tabular}

$\mathrm{R}^{2}=56.0 \% \quad($ adj $) \mathrm{R}^{2}=53.0 \%$

\section{Exchange Rate Equation}

The exchange rate equation is specified as follows:

$\mathrm{E}=\mathrm{a}_{30}+\mathrm{a}_{31} \mathrm{BD}+\mathrm{a}_{32} \mathrm{R}^{*}+\mathrm{a}_{33} \mathrm{R}+\mathrm{a}_{34} \mathrm{M}+\mathrm{a}_{35} \mathrm{Y}+\mathrm{a}_{36} \mathrm{CF}+\mathrm{u}_{3}$.

Table 8: Coefficient Estimates of Exchange Rate Equation

\begin{tabular}{llllll}
\hline Predictor & Coef & SDV & t-ratio & p & VIF \\
\hline Constant & 85.857 & 6.512 & 13.18 & 0.000 & \\
BD & -0.59271 & 0.07765 & -7.63 & 0.000 & 13.9 \\
R* & -0.0610 & 0.6299 & -0.10 & 0.923 & 2.4 \\
R' & 6.939 & 1.242 & 5.59 & 0.000 & 4.0 \\
Y & -0.029147 & 0.004183 & -6.97 & 0.000 & 12.4 \\
CF* & 0.0003415 & 0.0001328 & 2.57 & 0.013 & 2.3 \\
\hline
\end{tabular}

$\mathrm{R}^{2}=60.2 \% \quad(\operatorname{adj}) \mathrm{R}^{2}=56.8 \%$

Table 9: Exchange Rate Equation Excluding Y

\begin{tabular}{llllll}
\hline Predictor & Coef & SDV & t-ratio & p & VIF \\
\hline Constant & 108.552 & 7.039 & 15.42 & 0.000 & \\
BD & -0.47226 & 0.06262 & -7.54 & 0.000 & 9.0 \\
R* & -0.0630 & 0.6317 & -0.10 & 0.921 & 2.4 \\
R' & 3.746 & 1.023 & 3.66 & 0.001 & 2.7 \\
M & -0.15435 & 0.02229 & -6.93 & 0.000 & 7.8 \\
CF* & 0.0003261 & 0.0001328 & 2.45 & 0.017 & 2.3 \\
\hline
\end{tabular}

$\mathrm{R}^{2}=60.0 \% \quad(\operatorname{adj}) \mathrm{R}^{2}=56.6 \%$

Interest Rate Equation

A simple portfolio balance model is used to specify the determinants of the interest rate as follows:

$R=a_{40}+a_{41} E+a_{42} B D+a_{43} Y+a_{44} M+a_{45} C F+u_{4}$

The expected theoretical sign of the coefficients are as follows:

Variable: $\quad$ E $\quad$ BD $\quad$ Y $\quad M \quad$ CF

Sign: 
Table 10: Coefficient Estimates of Interest Rate Equation

\begin{tabular}{llllll}
\hline Predictor & Coef & SDV & t-ratio & p & VIF \\
\hline Constant & 7.243 & 5.327 & 1.36 & 0.179 & \\
BD & 0.03767 & 0.01515 & 2.49 & 0.016 & 25.0 \\
Y & 0.009167 & 0.001654 & 5.54 & 0.000 & 91.2 \\
M & -0.04884 & 0.01498 & -3.26 & 0.002 & 166.2 \\
E* & -0.00041 & 0.03898 & -0.01 & 0.992 & 7.2 \\
CF* $^{*}$ & -0.00135 & 0.02270 & -0.06 & 0.953 & 3.1 \\
\hline
\end{tabular}

$\mathrm{R}^{2}=67.6 \% \quad(\mathrm{adj}) \mathrm{R}^{2}=64.8 \%$

Table 11: Interest Rate Equation Excluding M

\begin{tabular}{llllll}
\hline Predictor & Coef & SDV & t-ratio & p & VIF \\
\hline Constant & -8.376 & 2.516 & -3.33 & 0.002 & 7.4 \\
BD & 0.079170 & 0.008870 & 8.93 & 0.000 & 5.6 \\
Y & 0.0039402 & 0.0004423 & 8.91 & 0.000 & 1.9 \\
E* & 0.10928 & 0.02127 & 5.14 & 0.000 & 2.3 \\
CF & -0.03836 & 0.02121 & -1.81 & 0.076 & \\
\hline
\end{tabular}

$\mathrm{R}^{2}=61.6 \%,(\operatorname{adj}) \mathrm{R}^{2}=59.0$

\section{CONCLUSION}

The size of U.S. federal budget deficit and its impact upon macro economic variables have been the subject of investigation by many economists. In view of majority of economists, government budget deficits are creating economic problems such as high real rates of interest, low savings, stagnant economic growth, large and persistent current account deficits, and probably a higher inflation. This view, however, is not shared by all economists. Some economists associated with the writings of Robert Barro argue that budget deficits do not matter and they have no real effects on the economy. Evidence presented in this paper indicates that budget deficits do matter and the Ricardian equivalence theorem is contradicted by data. The empirical results also indicate that federal deficits have contributed to trade deficits, capital inflows, and appreciation of the U.S. dollar. Empirical analysis further indicates that budget deficits did not raise interest rates. The fact that interest rates failed to rise in the 1980s, despite the large and persistent government budget deficits may be due to capital inflows into the United States.

\section{REFERENCES}

1. Alse Janardhanan, and Bahmani-Oskooee, Mohsen, 1992 Are the Twin Deficits Really Related? A Comment, Contemporary Policy Issues, Vol. 1, 108-111.

2. Bahmani-Oskooee, Mohsen, 1990, Deterioration in the Terms of Trade Improves the Balance of Payments Even if not the Trade Balance:Some Evidence from LDCs, Quarterly Review of Economics and Business, Vol.30,73-84.

3. _ 1989,Effect of U.S. Government Budget on Its Current Account: An Empirical Inquiry, Quarterly Review of Economics and Business, vol. 29,76-91.

4. 1991 On the Effect of U.S. Federal Deficits on Its Trade Flows, Journal of post Keynesian Economics, vol. 14, 72-82.

5. Bahmani-Oskooee, Mohsen, and Payesteh, Sayeed, 1994 Do Budget Deficits Cause Capital Inflows? Evidence From the United States, The Quarterly Review of Economics and Finance, Vol. 34, No. 1,63-74.

6. Bahmani-Oskooee, Mohsen, and Payesteh, Sayeed, 1993 Budget Deficits and the Value of Dollar: An Application of Cointegration and Error Correction Modeling", Journal of Macroeconomics, Vol.15, No. 4, 661-677

7. Bahmani-Oskooee, Mohsen, and Pourheydarian, Mohammad, 1990 Exchange rate Sensitivity of the Demand for Money and the Effectiveness of Fiscal and Monetary Policy, Applied Economics, Vol. 22, 917-923. 
8. Barro Robert J., 1989 The Ricardian Approach to Budget Deficits, Journal of Economic Prospective, Vol. 3, No.2 pp. 37-54.

9. $\quad$ 1987, Government Spending, Interest Rates, Prices, and Budget Deficits in the United Kingdom, 1701-1918, Journal of Monetary Economics, Vol. 20, 221-247.

10. Barth, James R., George Iden, and Frank S. Russek, 1985 Federal Borrowing and Short-term Interest Rates: Comment, Southern Economic Journal, Vol. 52, 554-559.

11. Biswas Basudeb, Gopal Tribedy, and Peter Saundrers, 1992 Further Analysis of the Twin Deficits, Contemporary Policy Issues, Vol. 10, 104-107.

12. Cebula, Richard J., 1990, Federal Government Budget Deficits and Interest Rate: Reply, Southern Economic Journal, Vol. 56, 804- 806.

13. Cebula, Richard J., and Koch, James V., 1989, An Empirical Note on Interest Rates, and International Capital Flows, Quarterly Review of Economics and Business, vol. 29, 121-127.

14. Darrat, Ali, 1988, Have large budget Deficits Caused Rising Trade Deficits?, Southern Economic Journal, Vol. 54, 879887.

15. 1990, Structural Deficits and Interest Rates: Some Causality and Co-Integration, Southern Economic Journal, Vol. 56, 752-759

16. Eisner, Robert, 1989, Budget Deficits: Rhetoric and Reality, Journal of Economic Prospective, Vol. 3, No.2, 7393.

17. Evans, Paul, 1986, Is the Dollar High Because of Large Budget Deficit?, Journal of Monetary Economics, Vol. 18, 34-55.

18. _ 1987a, Do Budget Deficit Rise Nominal Interest Rates? Evidence from Six Countries, Journal of Monetary Economics, Vol. 20, 281-300.

19. $\quad$ 1987b, Interest Rates and Expected Future Deficits in the United States, Journal of Political Economy, Vol., 34-55.

20. Friedman, Benjamin M., 1988, Day of Reckoning: The consequences of American Economic Policy under Reagan and After, Random House, New York.

21. Haas, Richard D., and William E. Alexander, 1979, A model of Exchange Rates and Capital Flows: The Canadian Floating Rate Experience, Journal of Money, Credit and Banking, Vol. 11, 467-482.

22. Hoelscher, Gregory, 1986, New Evidence on Deficits and Interest Rates, Journal of Money, Credit and Banking, Vol. 18, 1-17.

23. Holloway, Thomas M., 1986, The Cyclically Adjusted Federal Budget and Federal Debt: Revised and Updated Estimates, Survey of Current Business, Vol. 66, 11-17.

24. Johnston, J., 1984, Econometric Methods, McGraw-Hill, Inc.

25. Kreicher, Lawrence L., 1981, International Portfolio Capital Flows and Real Rates of Interest, The Review of Economics and Statistics, Vol. 63, 20-26.

26. McMillin, W. D., 1986, Federal Deficits and Short-Term Interest Rates, Journal of Macroeconomics, Vol. 8, 403-42.

27. Miller, Stephen M. and FranK S. Russek, 1989, Are the Twin Deficits Really Related?, Contemporary Policy Issues, Vol. 7, 91-115.

28. $\quad$ 1991, The Temporal Causality Between Fiscal Deficits and Interest Rates, Contemporary Policy Issues, Vol. 9, 12-23.

29. Mundelle, Robert, 1963, Capital Mobility and Stabilization Policy under Fixed and Flexible Exchange Rates, Canadian Journal of Economics and Political Science, Vol. 29, 475-485.

30. Mussa Michael, 1976, The Exchange Rate, the Balance of Payments and Monetary and Fiscal Policy under a Regime of Controlled Floating, Scandinavian Journal of Economics, No. 2, 229-248.

31. Neter John, Wasserman William, and Kutner Michael H., 1990, Applied Linear Statistical Models, 3th ed., Irwin.

32. Ostrosky, Anthony L., 1990, Federal Government Budget Deficits and Interest Rate: Comment, Southern Economic Journal, Vol. 56, No. 3, 802.

33. Zahid, Khan H., 1988, Government Budget Deficits and Interest Rates: The Evidence Since 1971 Using Alternative Deficits Measures, Southern Economic Journal, Vol. 54, 725-731. 
NOTES 